\title{
Publications on elder law within the Norma Elder Law Research Environment
}

Martina Axmin, 'Health care - a right without borders also for the elderly?' in Ann Numhauser-Henning (ed.), Introduction to the Norma Elder Law Research Environment - Different Approaches to Elder Law (The Norma Research Programme, Faculty of Law, Lund University 2013)

Alysia Blackham, 'Addressing the ageing workforce: a critical examination of legal policy objectives and values in the United Kingdom' (2016) Ageing and Society (forthcoming)

Helene Brodin and Titti Mattsson, 'Lägst ned på skalan? Hälso- och sjukvårdens bemötande av äldre kvinnor som migrerat till Sverige' (2014) 21(3-4) Socialvetenskaplig Tidskrift 372

Linus Broström, Mats Johansson and Titti Mattsson, 'Registrering av beslutsoförmögna för forskning, statistik och systematiskt förbättringsarbete' (2014) 3 Förvaltningsrättslig Tidskrift 369

Judy Fudge and Ania Zbyszewska, 'An intersectional approach to age discrimination in the European Union: bridging dignity and distribution?' in Ann Numhauser-Henning and Mia Rönnmar (eds), Age Discrimination and Labour Law, Comparative and Conceptual Perspectives in the EU and Beyond (Kluwer Law International 2015)

Emma Holm, 'Pensions on the move' in Ann Numhauser-Henning (ed.), Introduction to the Norma Elder Law Research Environment - Different Approaches to Elder Law (The Norma Research Programme, Faculty of Law, Lund University 2013)

Emma Holm, 'Fri rörlighet och tillgång till sociala förmåner för ickeförvärvsaktiva - har unionsmedborgarskapet kommit till vägs ände?' (2015) 2 Förvaltningsrättslig Tidskrift 225 
Jenny Julén Votinius, 'Intersections of age and gender' in Ann Numhauser-Henning (ed.), Introduction to the Norma Elder Law Research Environment - Different Approaches to Elder Law (The Norma Research Programme, Faculty of Law, Lund University 2013)

Jenny Julén Votinius, 'Age discrimination and labour law in Sweden' in Ann Numhauser-Henning and Mia Rönnmar (eds), Age Discrimination and Labour Law, Comparative and Conceptual Perspectives in the EU and Beyond (Kluwer Law International 2015)

Jenny Julén Votinius, 'Intersectionality as a tool for analysing age and gender in labour law' in Simonetta Manfredi and Lucy Vickers (eds), Challenges of Active Ageing (Palgrave Macmillan 2016)

Håkan Jönsson and Titti Mattsson (eds), 'Special Issue - Likvärdighet och äldreomsorg' (2014) 21 3-4 Socialvetenskaplig Tidskrift

Mirjam Katzin, 'Citizens as customers - social rights and the marketization of elder care' in Ann Numhauser-Henning (ed.), Introduction to the Norma Elder Law Research Environment - Different Approaches to Elder Law (The Norma Research Programme, Faculty of Law, Lund University 2013)

Mirjam Katzin, 'Tillbaka till familjen: privat och offentligt ansvar i den svenska äldreomsorgen’ (2014) 2 Retfaerd 37

Mirjam Katzin, 'Valfrihet istället för jämlikhet - förändrade målsättningar för äldreomsorgspolitiken?' (2014) 21(3-4) Socialvetenskaplig Tidskrift 310

Miriam Kullmann, 'Extending working life: the Dutch government's response' (2016) 1 European Labour Law Journal

Titti Mattsson, 'Rätten att få åldras tillsammans - en fråga om skälig levnadsnivå' (2012) Blendow Lexnova Expertkommentar

Titti Mattsson, 'A right to active ageing for all? On the status of the elderly in social services and health care' in Ann Numhauser-Henning (ed.), Introduction to the Norma Elder Law Research Environment Different Approaches to Elder Law (The Norma Research Programme, Faculty of Law, Lund University 2013) 
Titti Mattsson, 'National ombudsman for the elderly: a solution for a more responsive welfare state?' (2013) 142(3) Retfaerd 9

Titti Mattsson, 'Registrering av äldre patienter för kvalitetsutveckling och forskning' (2013) Blendow Lexnova Expertkommentar

Titti Mattsson, 'Patient safety at odds with patient privacy? The case of national and regional quality registries for incapacitated elderly in Sweden' (2014) (Special issue IV EAHL Conference) Lex Medicinae 69

Titti Mattsson, 'Collecting data for quality improvement and research in Swedish health care, and the individual patient's right and ability to protect their privacy' The International Journal of Technology Policy and Law Pages (forthcoming)

Titti Mattsson, 'E-government for the distribution of public services in Sweden: privatization, vulnerability and social responsibility reshaped' in Martha Albertson Fineman, Ulrika Andersson and Titti Mattsson (eds), Privatization, Vulnerability, and Social Responsibility: A Comparative Perspective (Routledge 2017)

Titti Mattsson, "Participation" for all? Challenges and tools for realizing the goal for vulnerable people with focus on health services' in Marlies Hesselman, Antenor Hallo de Wolf and Brigit Toebes (eds), SocioEconomic Rights in Essential Public Services Provision (Routledge Press 2016)

Per Norberg, 'Sickness Insurance Reform and the Elderly' in Ann Numhauser-Henning (ed.), Introduction to the Norma Elder Law Research Environment - Different Approaches to Elder Law (The Norma Research Programme, Faculty of Law, Lund University 2013)

Per Norberg, 'Hem eller vårdplats - hur behandlas personer med omsorgsbehov i hyreslagstiftningen?' (2014) 21(3-4) Socialvetenskaplig Tidskrift 350

Ann Numhauser-Henning, 'Om avgång i samband med pension och åldersdiskriminering' in Birgitta Nyström, Örjan Edström and Jonas Malmberg (eds), Nedslag $i$ den nya arbetsrätten (Liber 2012)

Ann Numhauser-Henning, 'Age discrimination and compulsory retirement' in Ann Numhauser-Henning (ed.), Introduction to the Norma Elder 
Law Research Environment - Different Approaches to Elder Law (The Norma Research Programme, Faculty of Law, Lund University 2013)

Ann Numhauser-Henning, 'Äldrerätt - ett nytt forskningsfält inför stora utmaningar' in Aslak Syse and others (eds), Velferd og rettferd, Festskrift til Asbjörn Kjönstad 70 år (Gyldendal Juridisk 2013)

Ann Numhauser-Henning, 'An introduction to elder law and the Norma Elder Law Research Environment' (2013) 3 Eur J of Soc L

Ann Numhauser-Henning, 'An introduction to elder law and the Norma Elder Law Research Environment: age discrimination and compulsory retirement' in Ann Numhauser-Henning (ed.), Introduction to the Norma Elder Law Research Environment Different Approaches to Elder Law (The Norma Research Programme, Faculty of Law, Lund University 2013)

Ann Numhauser-Henning, 'Introduction to the Norma Elder Law Research Environment Different approaches to elder law' in Ann Numhauser-Henning (ed.), Introduction to the Norma Elder Law Research Environment - Different Approaches to Elder Law (The Norma Research Programme, Faculty of Law, Lund University 2013)

Ann Numhauser-Henning, 'Labour law in a greying labour market - in need of a reconceptualisation of work and pension norms, the position of older workers in labour law' (2013) 4(2) Eur Lab L J 84

Ann Numhauser-Henning, 'The EU ban on age-discrimination and older workers: potentials and pitfalls' (2013) 29(4) IJCLLIR 391

Ann Numhauser-Henning, 'La prohibición de la UE contra la discriminación por edad y el papel de los agentes sociales' (2014) El derecho a la negociación colectiva, Liber Amicorum Profesor Antonio Ojeda Avilés (Junta de Andalucia 2014)

Ann Numhauser-Henning, 'Labour law in a greying labour market - in need of a reconceptualisation of work and pension norms' in Steven Willborn and Alan Neal (eds), Yearbook of Comparative Labour Law Scholarship (Lancaster House 2015)

Ann Numhauser-Henning, 'Labour law, pension norms and the EU ban on age discrimination: towards ultimate flexibilization?' in Ann 
Numhauser-Henning and Mia Rönnmar (eds), Age Discrimination and Labour Law, Comparative and Conceptual Perspectives in the EU and Beyond (Kluwer Law International 2015)

Ann Numhauser-Henning and Mia Rönnmar, 'Compulsory retirement and age discrimination - the Swedish Hörnfeldt case put in perspective' in Patrik Lindskoug and others (eds), Essays in Honour of Michael Bogdan (Juristförlaget i Lund 2013)

Ann Numhauser-Henning and Mia Rönnmar (eds), Age Discrimination and Labour Law, Comparative and Conceptual Perspectives in the EU and Beyond (Kluwer Law International 2015)

Ann Numhauser-Henning and Mia Rönnmar, 'Concluding discussion' in Ann Numhauser-Henning and Mia Rönnmar (eds), Age Discrimination and Labour Law, Comparative and Conceptual Perspectives in the EU and Beyond (Kluwer Law International 2015)

Ann Numhauser-Henning and Mia Rönnmar, 'Introduction' in Ann Numhauser-Henning and Mia Rönnmar (eds), Age Discrimination and Labour Law, Comparative and Conceptual Perspectives in the EU and Beyond (Kluwer Law International 2015)

Ann Numhauser-Henning and Mia Rönnmar, 'Age discrimination and labour law in a comparative perspective' in Laura Carlson, Örjan Edström and Birgitta Nyström (eds), Globalisation, Fragmentation, Labour and Employment Law - A Swedish Perspective (Iustus 2016)

Ann Numhauser-Henning and Mia Rönnmar, 'Age discrimination law and social partners and collective bargaining' in Bernhard Johann Mulder et al. (eds), Sui generis - Festskrift til Stein Evju (Universitetsforlaget Oslo 2016)

Hanna Pettersson, 'Challenge or opportunity? Perceptions of ageing in labour law and social security law' in Ann Numhauser-Henning (ed.), Introduction to the Norma Elder Law Research Environment - Different Approaches to Elder Law (The Norma Research Programme, Faculty of Law, Lund University 2013)

Hanna Pettersson, 'Döden - en privatsak? Socialförsäkringsrättsliga perspektiv på ansvarsfördelning vid närståendevård' (manuscript) 
Hanna Pettersson, 'Managing the ageing population: Swedish legal approaches to older workers in the 1970s and the 2010s' (manuscript)

Eva Ryrstedt, 'Civil rights of the elderly in a family law setting' in Ann Numhauser-Henning (ed.), Introduction to the Norma Elder Law Research Environment - Different Approaches to Elder Law (The Norma Research Programme, Faculty of Law, Lund University 2013)

Eva Ryrstedt, 'Får jag inte bestämma något själv? En studie av kvarstående beslutanderätt hos dementa äldre' (2014) 21(3-4) Socialvetenskaplig Tidskrift 328

Eva Ryrstedt, 'Dementa äldre personer; vem ska bestämma?' (2016) 1 Tidskrift utgiven av Juridiska Föreningen i Finland 179

Mia Rönnmar, 'Protection of established position, social protection and the legal situation of the elderly in the European Union' in Mia Rönnmar and Ann Numhauser-Henning (eds), Normative Patterns and Legal Developments in the Social Dimension of the EU (Hart Publishing 2013)

Mia Rönnmar, 'Flexicurity and the legal position of the elderly' in Ann Numhauser-Henning (ed.), Introduction to the Norma Elder Law Research Environment - Different Approaches to Elder Law (The Norma Research Programme, Faculty of Law, Lund University 2013)

Mia Rönnmar, Intergenerational Bargaining in Sweden. Report for the project iNGenBar (2014)

Mia Rönnmar 'Age discrimination and labour law: a comparative analysis' in Ann Numhauser-Henning and Mia Rönnmar (eds), Age Discrimination and Labour Law, Comparative and Conceptual Perspectives in the EU and Beyond (Kluwer Law International 2015)

Mia Rönnmar, 'Elder Law' (2015) September/Oktober Recht der Arbeit 305

Mia Rönnmar, Older Workers and 'Stayers' in the Swedish Labour Market: An Analysis of the Legal Framework (Report for the project 'Towards sustainable ageing: a life course perspective' funded by the Kamprad Family Foundation 2016) 
Beryl Ter Haar and Mia Rönnmar, Intergenerational Bargaining, EU Age Discrimination Law and EU Policies - and Integrated Analysis, Report for the project iNGenBar (2014)

Carin Ulander-Wänman, 'Swedish collective agreements and employers' willingness to hire and retain older workers in employment' (2016) 6(2) Nordic Journal of Working Life Studies 61-79

Carin Ulander-Wänman, 'The Swedish occupational pension scheme ITP2 - a limiting factor for older employees' employability?' (manuscript)

Ania Zbyszewska, 'Active aging through employment: a critical feminist perspective on Polish policy' (2016) Int J Comp Lab Law and Indus Relations (forthcoming) 